\title{
Nutrient and sediment dynamics in a Mediterranean shallow lake in southwest Spain
}

\author{
Inmaculada de Vicente ${ }^{1, *}$, Raquel López ${ }^{2}$, Inmaculada Pozo ${ }^{1}$ and Andy J. Green ${ }^{2}$ \\ ${ }^{1}$ Water Research Institute, University of Granada, C/Ramon y Cajal, No 4, 18071, Granada. \\ ${ }^{2}$ Dept. of Wetland Ecology, Estación Biológica de Doñana, EBD-CSIC, C/ Américo Vespucio 41092, Sevilla. \\ * Corresponding author: ivicente@ugr.es
}

Received: 7/4/11 Accepted: 6/2/12

\begin{abstract}
Nutrient and sediment dynamics in a Mediterranean shallow lake in southwest Spain

Temporal and spatial variations in the nutrient concentrations of lake water and surface sediments and in settling and resuspension rates were assessed in a Mediterranean shallow lake (Medina Lake, southern Spain) using a combination of shortterm and long-time monitoring. Our results confirmed the high temporal (inter- and intra-annual) variability characterising Mediterranean shallow lakes, which is also enhanced by water level fluctuations. The results also underlined the crucial role of phosphorus $(\mathrm{P})$ exchange across the sediment-water interface in controlling $\mathrm{P}$ dynamics in lake water. This statement is supported by (i) the existence in the upper $1 \mathrm{~cm}$ of the sediment of 18 times the mass of TP of the whole water column and, hence, the high potential impact of P released from the sediment into the overlying column and by (ii) the strong P limitation of planktonic primary production, as reflected by a DIN:TP atomic ratio much higher than 16 . Resuspension, co-precipitation with $\mathrm{CaCO}_{3}$ and adsorption onto iron hydroxides $(\mathrm{FeOOH})$ all had major effects on the $\mathrm{P}$ exchange across the sediment-water interface. Wind-induced resuspension $(31 \pm 13 \%$ of the settled matter) explained the extremely high gross sedimentation rates $\left(40 \pm 11 \mathrm{~g} \mathrm{~m}^{-2} \mathrm{~d}^{-1}\right)$ recorded for a $24 \mathrm{~h}$ period. $\mathrm{P}$ adsorption onto $\mathrm{FeOOH}$ controlled internal $\mathrm{P}$ loading during the winter (FeOOH: $\left.\mathrm{P}_{\text {mobile }}>15\right)$. During the summer, the low availability of $\mathrm{FeOOH}\left(\mathrm{Fe}: \mathrm{P}_{\text {mobile }}<15\right)$ reflected the inability of $\mathrm{FeOOH}$ to control $\mathrm{P}$ adsorption. The SRP concentrations in lake water were much higher than necessary for $\mathrm{CaCO}_{3}$ and $\mathrm{P}$ co-precipitation, explaining the high contribution of $\mathrm{P}$ bound to $\mathrm{CaCO}_{3}\left(\mathrm{P}_{\mathrm{HCl}}\right)$ to the total $\mathrm{P}$ in the sediment of the study site and demonstrating the importance of $\mathrm{CaCO}_{3}$ precipitation for removing $\mathrm{P}$ from lake water.
\end{abstract}

Key words: Mediterranean shallow lakes, phosphorus, sediment, resuspension.

\section{RESUMEN}

\section{Dinámica de los nutrientes y del sedimento en un lago somero Mediterráneo}

En este trabajo se estudia la distribución temporal y espacial de los nutrientes en el agua y en el sedimento superficial así como las tasas de sedimentación y resuspensión en una laguna somera Mediterránea (laguna de Medina, Sur de España). Para ello se ha empleado una doble aproximación basada en un seguimiento a corto (muestreos intensivos) y a largo plazo (seguimiento estacional). Nuestros resultados han confirmado la elevada variabilidad temporal (inter e intra-anual) que caracteriza a los lagos someros mediterráneos, y que es favorecida por las fluctuaciones en el nivel de agua. Además, se ha observado el importante papel que juega el intercambio de fósforo $(P)$ a través de la interfase agua-sedimento sobre la dinámica de este nutriente en la columna de agua. Esta afirmación se sustenta en: (i) la existencia en el sedimento superficial (1 cm) de 18 veces la masa de TP presente en toda la columna de agua; y en (ii) la fuerte limitación de la producción primaria planctónica por $P$, reflejada por una razón atómica DIN:TP muy superior a 16. La resuspensión, la precipitación con carbonato cálcico $\left(\mathrm{CaCO}_{3}\right)$ y la adsorción sobre hidróxidos de hierro ( $\mathrm{FeOOH}$ ) son los procesos físicos y químicos más relevantes que afectan al intercambio de $P$ en la interfase agua-sedimento. La resuspensión ( $31 \pm 13 \%$ del material sestónico) inducida por el viento es el principal factor responsable de la extremadamente elevada tasa de sedimentación de partículas en la laguna de Medina $\left(40 \pm 11 \mathrm{~g} \mathrm{~m}^{-2} \mathrm{~d}^{-1}\right)$, registradas durante períodos de $24 \mathrm{~h}$. Por otro lado, la adsorción de P sobre FeOOH limita la carga interna de P durante el invierno ( $\mathrm{FeOOH}: P_{\text {móvil }}>15$ ); mientras que durante el verano, la escasa disponibilidad de $\mathrm{FeOOH}$ $\left(\mathrm{Fe}: P_{\text {móvil }}<15\right)$ indica un papel secundario de los $\mathrm{FeOOH}$ en el control de la carga interna de P. Finalmente, la existencia de concentraciones de fósforo reactivo soluble (SRP) en la columna de agua muy superiores a las estimadas como necesarias 
para que tenga lugar la co-precipitación con $\mathrm{CaCO}_{3}$, es la responsable de que la fracción más importante de P sedimentario sea la asociada al $\mathrm{CaCO}_{3}$, confirmando la importancia de este proceso químico para la retención de P en el sedimento.

Palabras clave: Lagos someros Mediterráneos, fósforo, sedimento, resuspensión.

\section{INTRODUCTION}

Shallow lakes can be defined as more or less permanent standing water bodies that are shallow enough to potentially allow light penetration to the lake bottom and are frequently colonised by higher aquatic plants (Meerhoff \& Jeppesen, 2009). Shallow lakes are also defined as polymictic, as they do not stratify for long periods in the summer and the entire water column is frequently mixed (Scheffer, 1998). The average depth of most of these aquatic ecosystems is less than $3 \mathrm{~m}$. Since the 1990s, it has generally been accepted that, over a range of nutrient concentrations, shallow temperate lakes can have two alternative equilibrium states: a clear state dominated by aquatic vegetation and a turbid state characterised by high algal biomass (Scheffer et al., 1993). Aquatic vegetation can stabilise a clear-water state in shallow lakes up to relatively high nutrient loadings, but once the system has switched to a turbid state, a strong nutrient reduction is required to enable recolonisation by plants (Scheffer, 1998). The high surface area to maximum depth ratio and the typical polymixis that characterise shallow lakes are also responsible for an intense benthic-pelagic coupling. In fact, shallow lake functioning is subject to much temporal variability, and a major factor contributing to their marked instability is the close link between bottom sediments and overlying waters (de Vicente et al., 2006a). This sedimentwater interaction is extremely important for understanding the nutrient dynamics of the water column (Ryding, 1985; Boström et al., 1988).

On a global scale, shallow lakes constitute a larger proportion of inland waters than hitherto believed (i.e., Downing, 2010). Their relevance is even greater in the Iberian Peninsula due to the scarcity of natural inland waters. Mediterranean shallow lakes are characterised by extreme natural fluctuations in water levels in response to irregular precipitation patterns (Álvarez-Cobelas et al., 2005). The Mediterranean climate is characterised by dry, hot summers and mild winters with irregular precipitation, most of which occurs from October to February. As a consequence of the water level fluctuations, a portion of the lake sediment is exposed to air-drying in dry years when the water table becomes low, affecting those phosphate-binding properties of the lake sediment that are related to iron and aluminium oxides/hydroxides (de Vicente et al., 2010a). Accordingly, water level fluctuations are likely to enhance the intense nutrient exchange across the sediment-water interface that characterises shallow lakes.

Sediments may affect water quality as a consequence of their dynamic and active character, resulting from a great variety of biogeochemical reactions and transformations. The resuspension of unconsolidated sediment usually plays a fundamental role in shallow lakes, where sediments are often subjected to continuous wave action (Kristensen et al., 1992; Nõges et al., 1999; Weyhenmeyer \& Bloesch, 2001; de Vicente et $a l ., 2010 b)$. Evidence for the importance of resuspension is plentiful (Kristensen et al., 1992; Bloesch, 1995; Weyhenmeyer et al., 1995). Resuspension rates can be estimated using different methodological approaches. Because sedimentation traps provide an estimation of the gross sedimentation flux rather than the net sedimentation flux (Bloesch, 1982), two different methods for estimating the contribution of resuspended matter to settled matter have been developed. First, and assuming that in relatively deep lakes resuspension only affects the bottom waters, the comparison between the settling rates measured at traps located close to the surface of the sediment with 
those measured at traps farther above provides information about the resuspension rate (Bloesch, 1995; Kleeberg, 2002). However, the application of this method is limited in shallow lakes because the upper traps may also be affected by resuspended matter at certain times, which reveals the inherent difficulties in identifying an appropriate reference level (Bloesch, 1994). A second methodological approach for estimating resuspension rates is based on the use of $\mathrm{Fe}$ as a sediment tracer due to its generally low concentration in settled organic material (Jensen, pers. comm.). Hence, the contribution of resuspended matter to settling rates can be estimated by comparing the total iron (TFe) concentrations of both materials (surface sediments and settled matter) during periods without any inflow.

Apart from wind-induced resuspension, $\mathrm{P}$ cycling in shallow lakes strongly depends on biological processes, as most of the organic matter produced in the water column reaches the sediment without being mineralised, and also on chemical reactions (adsorption and precipitation) that are essentially mediated by iron oxides $(\mathrm{FeOOH})$ and calcium carbonate $\left(\mathrm{CaCO}_{3}\right)$. The study of the chemical processes occurring at the sediment-water interface in deeper lakes has traditionally focused on the chemistry of Fe and $\mathrm{P}$ compounds, which ultimately depends on $\mathrm{O}_{2}$ availability (Mortimer, 1941) and on the Fe:P ratio (i.e., Jensen et al., 1992; Gächter \& Wehrli, 1998; Gächter \& Müller, 2003).
However, $\mathrm{CaCO}_{3}$ precipitation is a very common process in hard water lakes and ultimately affects P dynamics (Otzuki \& Wetzel, 1972; Koschel et al., 1983; Rodrigo et al., 1993; Dittrich \& Koschel, 2002). Therefore, the endorheic nature, and thus the highly mineralised waters, of most Iberian shallow lakes suggests that $\mathrm{P}$ removal from the water column mediated by $\mathrm{CaCO}_{3}$ precipitation may be a crucial mechanism affecting $\mathrm{P}$ availability in these ecosystems.

The present study was carried out in a Mediterranean shallow lake (Medina Lake) located in a calcareous endorheic area (Jerez de la Frontera, south-western Spain). As a consequence of its morphometry and geographic location (a low-lying, windy area), this lake represents an ideal site for achieving a better understanding of the temporal variability in the interactions between meteorology, biogeochemistry and physics. In addition, the $\mathrm{P}$ limitation of primary production in the study site (see below) makes it vital to gain knowledge about $P$ exchange across the sediment-water interface. In particular, the aims of this study are the following: i) to study the spatial and temporal (on a daily and on a two-year scale) variations in dissolved inorganic and total nutrients ( $\mathrm{N}$ and $\mathrm{P})$, total suspended matter and chlorophyll $a$; ii) to determine the gross and net settling flux by assessing the contribution of resuspended matter; and iii) to quantify the spatial and temporal distribution of sedimentary $\mathrm{P}$ fractions to estimate

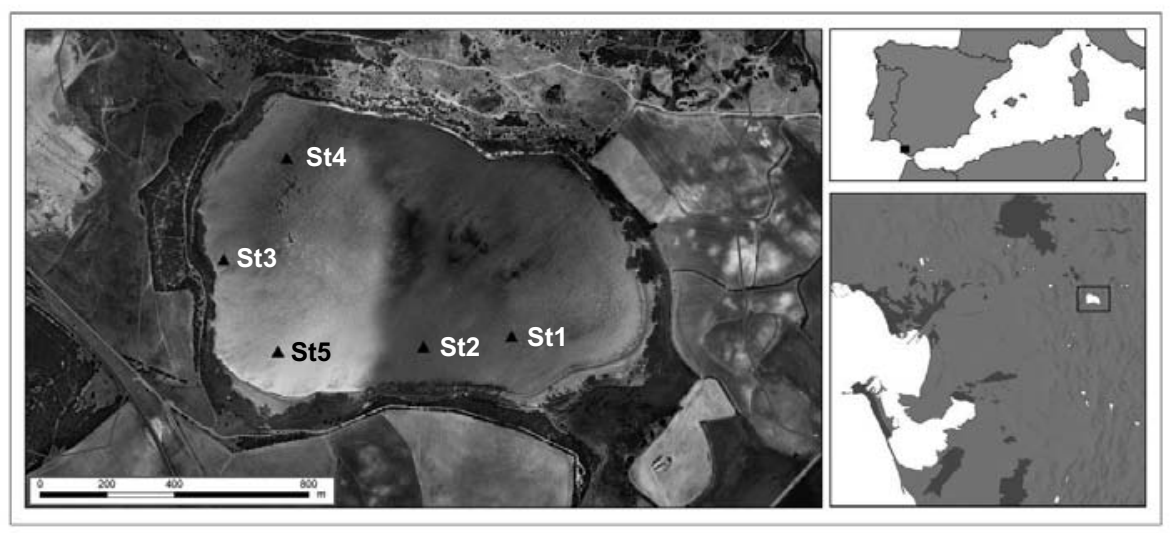

Figure 1. Geographic location of Medina Lake (Cádiz, Spain). Triangles indicate the 5 sampling stations. Localización geográfica de la laguna de Medina (Cádiz, España). Los triángulos indican las 5 estaciones de muestreo. 
the potential contribution of sedimentary $\mathrm{P}$ to the availability of $\mathrm{P}$ in the water column.

\section{MATERIAL AND METHODS}

\section{Study site}

Medina Lake (c. 120 ha) is the second largest inland playa lake in Andalusia (Table 1, Fig. 1). Although there is no universal definition for playa lakes (Smith, 2003), Rodríguez-Rodríguez (2007) defined them as shallow water bodies without outlets and with a closed (endorheic) watershed made up of permeable or semi-permeable materials. More than $85 \%$ of the Medina watershed is occupied by low-permeability marls and clays deposited during the Triassic period and then thrust upward, forming rocks known as olistolites (Benavente et al., 2005). The

Table 1. Primary limnological features of Medina Lake. ${ }^{*}$ Min-Max (Median) for the period 2002-2006 $(n=10)$. TA is total alkalinity. Morphometric features are those present when the lake is at full capacity. Data provided by Consejería de Medio Ambiente, Junta de Andalucía. *Características limnológicas principales de la Laguna Medina. Min-Max (Mediana) durante el periodo 2002-2006 ( $\mathrm{n}=10)$. TA es la alcalinidad total. Las características morfométricas presentadas son aquellas cuando la laguna se encuentra al máximo de su capacidad. Datos proporcionados por la Consejería de Medio Ambiente, Junta de Andalucía.

\begin{tabular}{ll}
\hline Lake area (ha) & 120 \\
Maximum length $(\mathrm{m})$ & 1500 \\
Maximum width $(\mathrm{m})$ & 750 \\
Watershed area (ha) & 1800 \\
Maximum depth (m) & 3.5 \\
Mean depth (m) & 1.8 \\
Volume $\left(\mathrm{hm}^{3}\right)$ & 3.610 \\
$\mathrm{~T}\left({ }^{\circ} \mathrm{C}\right)^{*}$ & $10.80-28.30(20.65)$ \\
$\mathrm{Cond}\left(\mathrm{mS} \mathrm{cm}^{-1}\right)^{*}$ & $4.65-12.88(6.11)$ \\
$\mathrm{pH}^{*}$ & $7.60-8.90(7.98)$ \\
$\mathrm{O}_{2}\left(\mathrm{mg} \mathrm{l}^{-1}\right)^{*}$ & $3.84-12.01(10.22)$ \\
$\left.\mathrm{SD}^{*}\right)^{*}$ & $0.08-2.62(0.44)$ \\
$\left.\mathrm{TSS}^{-1} \mathrm{mg} \mathrm{l}^{-1}\right)^{*}$ & $3-510(72)$ \\
$\mathrm{Ca}^{2+}\left(\mathrm{mg} \mathrm{l}^{-1}\right)^{*}$ & $268.2-709.0(407.5)$ \\
$\mathrm{Mg}^{2+}\left(\mathrm{mg} \mathrm{l}^{-1}\right)^{*}$ & $206.8-720.0(320.0)$ \\
$\mathrm{K}^{+}\left(\mathrm{mg} \mathrm{l}^{-1}\right)^{*}$ & $16.4-48.4(22.3)$ \\
$\mathrm{Na}^{+}\left(\mathrm{mg} \mathrm{l}^{-1}\right)^{*}$ & $421.0-1735.0(638.6)$ \\
$\mathrm{Cl}^{-}\left(\mathrm{mg} \mathrm{l}^{-1}\right)^{*}$ & $820.5-2914.9(1238.8)$ \\
$\mathrm{SO}_{4}^{2-}\left(\mathrm{mg} \mathrm{l}^{-1}\right)^{*}$ & $1146.0-3994.0(1887.7)$ \\
$\left.\mathrm{TA}^{\left(m e q ~ l^{-1}\right.}\right)^{*}$ & $0.80-2.60(2.13)$ \\
\hline
\end{tabular}

substratum over which the playa lake formed inhibits downward percolation and groundwater recharge (Rodríguez-Rodríguez et al. 2011). Thus, Medina Lake can be considered a discharge playa lake (Yecchieli \& Wood 2002), where the main form of water output is evapotranspiration. The hydroperiod is altered by an artificial overflow that is linked to a ditch and was constructed to prevent the flooding of adjacent fields (Rodríguez-Rodríguez et al., 2011). Medina Lake has suffered marked fluctuations in depth and salinity over the last 9000 years (Reed et al., 2001). The closed basin or watershed of 1748 ha is utilised primarily for wheat cultivation (Rodríguez-Rodríguez et al., 2011). The great importance of Medina Lake for water birds (e.g., Amat, 1984; Martínez-Haro et al., 2011) led to its protection as a nature reserve and its declaration as a Wetland of International Importance under the Ramsar Convention in 1989. Owing to formerly intense hunting activity, the lake sediments are highly contaminated with spent lead shot (Mateo et al., 2007). Recent management activities include the removal in September 2007 with rotenone of invasive and allochthonous carp (Cyprinus carpio, Linnaeus, 1758), which became established in the study site in 2003. In addition, 20 ha of crops in the area adjacent to the eastern shoreline were expropriated, enabling the restoration of natural vegetation from November 2007 onwards. Despite marked inter-annual variations in its limnological characteristics, some general features emerge. It is a polymictic lake. Its shallowness and the intensity and frequency of prevailing winds lead to thermal homogeneity in the vertical profile and a corresponding low mechanical resistance of the water column to mixing for most of the annual cycle. Medina Lake has a basic $\mathrm{pH}$ and a high alkalinity (Table 1). The lake waters are highly mineralised, with an ionic composition dominated by $\mathrm{SO}_{4}^{-2}-\mathrm{Cl}^{-}-\mathrm{Na}^{+}-\mathrm{Mg}^{+2}\left(\mathrm{Ca}^{+2}\right)$. Water transparency is particularly variable, with the highest values during the spring and summer, associated with the extensive development of macrophytes, especially Potamogeton pectinatus (Linnaeus, 1753) and Zannichellia obtusifolia (Talavera, García Murillo and Smit, 1986). 


\section{Meteorological Data and Morphometry}

Daily data on rainfall, evaporation, daily average wind speed and wind direction were provided by www.juntadeandalucia.es/agriculturaypesca/ifa $\mathrm{pa} /$ ria for the period 01/01/2008-11/10/2009. In addition, during our intensive, short-term monitoring periods (31/01/2008-01/02/2008 and 30/03/2008-01/04/2008), a meteorological station (HOBO Micro Station Logger [H21-002]) was placed nearby to record wind speed and wind direction every $15 \mathrm{~min}$. Data on morphometric variables were obtained from Consejería de Medio Ambiente (2007) (Table 1). Water level data were collected on a monthly basis by a limnimetric station.

\section{Water Column Monitoring}

From the winter of 2008 to the summer of 2009, eight surveys were conducted using a combination of short-term (daily) and long-term (two-years) monitoring to characterise the water column, settling/resuspension of particles and surface sediment. Two intensive samplings were carried out: 31/01/08-01/02/08 and 31/03/08$01 / 04 / 08$. On $31 / 01 / 08$, samples were collected at 17:00 and on 01/02/08 samples were collected at 10:00, 13:00 and 17:00, whereas from 31/03/08-01/04/08, samples were only collected once per day at 17:00. Because no significant changes occurred during the first intensive sampling period, only one result for each day (those measured at 17:00) is shown (see "Results" section). For the 2-year monitoring, seasonal samples (one per season) were collected.

Lake water samples were collected using a Van Dorn sampler at two different depths in the vertical profile $(10 \mathrm{~cm}$ below the surface and $20 \mathrm{~cm}$ above sediments) and at five sampling stations (Fig. 1). Once at the laboratory, total phosphorus (TP) and total nitrogen (TN) were directly determined from non-filtered water. TP was analysed as molybdate reactive P (Murphy \& Riley, 1972) after persulfate digestion (APHA, 1995), and TN was determined after alkaline digestion by using the UV spectrophotometric method (APHA, 1995). A subsample was filtered for the analysis of dissolved nutrients. Total dissolved phosphorus (TDP) and total dissolved nitrogen (TDN) were determined in filtered waters following the above methods for TP and $\mathrm{TN}$, respectively. Soluble reactive phosphorus (SRP) was measured using the molybdenum blue method described by Murphy \& Riley (1972). Nitrate $\left(\mathrm{NO}_{3}^{-}\right)$and nitrite $\left(\mathrm{NO}_{2}^{-}\right)$were analysed using UV spectrophotometry after acidification $(1 \mathrm{~N} \mathrm{HCl})$ and using the sulphanilamide and naphtil methods, respectively (Rodier, 1989). A phenol-hypochloride reaction was used for the determination of ammonium $\left(\mathrm{NH}_{4}^{+}\right)$(Rodier, 1989). Total particulate $\mathrm{P}$ (TPP) was estimated as the difference between TP and TDP. In addition, alkalinity was measured using the titrimetric method of determination (METROHM 716 DMS) for the filtered subsample. Chl $a$ concentration was measured using the trichromatic method of Jeffrey \& Humphrey (1975). Finally, total suspended solids (TSS) were quantified using a gravimetric method. The organic matter concentration in the suspended solids (particulate organic matter $=\mathrm{POM}$ ) was quantified using the ignition method (LOI) based on the difference in weight before and after the ignition of dried sediment $\left(520^{\circ} \mathrm{C}, 3 \mathrm{~h}\right)$. Analytical error was $0.01 \%$. Particulate inorganic matter (PIM) was estimated by subtracting POM from TSS.

\section{Resuspension and settling fluxes}

Cylindrical sedimentation traps (height/ diameter $=6.2$ ) were deployed in pairs $20 \mathrm{~cm}$ above the bottom at the five sampling stations (Fig. 1). The settled material was collected on two occasions (31/01/2008-01/02/2008 and 31/03/2008-01/04/ 2008). The short exposure time $(24 \mathrm{~h})$ of the sedimentation traps allowed us to assume that mineralisation losses were minor. In the laboratory, the suspension was filtered through Whatman $\mathrm{GF} / \mathrm{C}$ glass fibre filters and dried $\left(104^{\circ} \mathrm{C}\right.$, $24 \mathrm{~h}$ ). The sinking flux (S) of particulate material $\left(\mathrm{g} \mathrm{DW} \mathrm{m}^{-2} \mathrm{~d}^{-1}\right.$ ) was calculated as,

$$
S=M \cdot V_{T} \cdot V_{F}^{-1} \cdot A^{-1} \cdot T^{-1}
$$

where $M$ is the mass of particulate material quantified as the difference in the dry weight of the 
filters before and after filtering a known volume $\left(V_{F}\right)$ of the homogenised suspension sample; $V_{T}$ is the trap volume, $0.45 \mathrm{l} ; A$ is the collection area, $15.2 \mathrm{~cm}^{2}$ and $T$ is the time of trap exposure.

In the spring of $2008 \quad(31 / 03 / 2008-$ 01/04/2008), resuspended matter was sampled using a horizontal Van Dorn sampler, which was used to strike the lake bottom a few times to resuspend the sediment (Doremus \& Clesceri, 1982). Organic matter (OM) and TFe concentrations were determined in both the settling and resuspended matter. The concentration of $\mathrm{OM}$ (\%) was quantified as LOI $\left(520^{\circ} \mathrm{C}, 3 \mathrm{~h}\right)$. TFe was determined by igniting $\left(520^{\circ} \mathrm{C}, 3 \mathrm{~h}\right) 0.1 \mathrm{~g}$ of dry material followed by hot $1 \mathrm{M} \mathrm{HCl}$ extraction $\left(104^{\circ} \mathrm{C}, 1 \mathrm{~h}\right)$. Finally, TFe was measured spectrophotometrically using the ferrozine method (Gibbs, 1979). Considering $\mathrm{Fe}$ as a sediment tracer, the contribution of resuspended matter to settling rates was estimated by comparing the TFe concentrations in both materials during periods without any inflow.

\section{Chemical characterisation of surface sediment}

On two occasions (December 2008 and July 2009), three sediment cores were collected in acrylic tubes using a Kajak sampler at the five sampling stations. Once in the laboratory, sediment cores were sectioned and the upper sediment $(0-0.5 \mathrm{~cm})$ sections from the three cores corresponding to the same station were pooled before analysis. Fresh sediment was analysed for OM concentration, TFe and Fe (extracted in bicarbonate-dithionite (BD) solution) and the different sedimentary $\mathrm{P}$ fractions. All analyses were run in duplicate.

$\mathrm{P}$ speciation was determined using a slight modification of the sequential extraction method proposed by Paludan \& Jensen (1995), where the use of $1 \mathrm{M} \mathrm{MgCl}_{2}$ was replaced with distilled water for the extraction of weakly adsorbed $\mathrm{P}$ in the first step. In summary, this method is based on 5 sequential steps where 7 different forms of $\mathrm{P}$ may be discriminated: 1) water extractable $\mathrm{P}\left(\mathrm{P}_{\mathrm{H}_{2} \mathrm{O}}\right)$, 2) reductant extractable $\left.\mathrm{P}\left(\mathrm{P}_{\mathrm{BD}}\right), 3\right) \mathrm{NaOH}$ soluble, molybdate-reactive $\left.\mathrm{P}\left(\mathrm{iP}_{\mathrm{NaOH}}\right), 4\right) \mathrm{NaOH}$ extractable non-reactive (organic) $\left.\mathrm{P}\left(\mathrm{nrP}_{\mathrm{NaOH}}\right), 5\right)$
$\mathrm{P}$ recovered in humic precipitate (Humic-P), 6) $\mathrm{HCl}$ extractable $\mathrm{P}\left(\mathrm{P}_{\mathrm{HCl}}\right)$, and 7) residual $\mathrm{P}$ (Res$\mathrm{P}_{\mathrm{HCl}}$ ) extracted from the sediment residue after ignition and boiling with $1 \mathrm{M} \mathrm{HCl}$. For $\mathrm{P}$ fractionation, $1 \mathrm{~g}$ of wet sediment was shaken with $25 \mathrm{ml}$ of each extractant solution. In the first three extractions $\left(\mathrm{H}_{2} \mathrm{O}, \mathrm{BD}\right.$ and $\left.\mathrm{NaOH}\right)$, inorganic and organic $\mathrm{P}$ (non-reactive) fractions were distinguished by digesting (organic and inorganic $\mathrm{P}$ ) or not digesting (inorganic $\mathrm{P}$ ) the supernatants before measuring $\mathrm{P}$ as molybdate-reactive $\mathrm{P}$ (Murphy \& Riley, 1972). From the difference between TP and SRP in the $\mathrm{P}_{\mathrm{H}_{2} \mathrm{O}}, \mathrm{P}_{\mathrm{BD}}$, and $\mathrm{P}_{\mathrm{NaOH}}$ extracts, the nrP was calculated. The sum of nrP in the three extracts is believed to represent labile $\mathrm{P}$ compounds (Reitzel et al., 2005). As Golterman (2001) noted, the addition of $\mathrm{NaOH}$ may cause the formation of hydroxi-apatite and the hydrolysis of organic compounds when the extraction time for $\mathrm{NaOH}$ is too long. However, in this study, the short extraction time (1 h) may have reduced the hydrolysis of organic compounds. The total $\mathrm{P}$ in the sediment $\left(\mathrm{TP}_{\text {sed }}\right)$ was determined for parallel non-extracted sediment samples by igniting $\left(520^{\circ} \mathrm{C}, 3 \mathrm{~h}\right) 0.1 \mathrm{~g}$ of dry sediment followed by a hot $1 \mathrm{M} \mathrm{HCl}$ extraction $\left(104^{\circ} \mathrm{C}, 1 \mathrm{~h}\right)$. The sum of the seven $\mathrm{P}$-pools never varied more than $10 \%$ from the parallel measurement of $\mathrm{TP}_{\text {sed }}$. As the latter measurement is considered more accurate, we normalised the sediment P-pools so that the sum of the pools equalled this value. Normalisation consisted of multiplying each sedimentary $\mathrm{P}$ fraction by the $\mathrm{TP}_{\text {sed }}$ and dividing by the sum of the $\mathrm{P}$ pools.

Potentially mobile phosphorus ( $\mathrm{P}$ mobile) was defined as the sum of porewater $\mathrm{P}\left(\mathrm{P}_{\mathrm{H}_{2} \mathrm{O}}\right)$, iron-bound $\mathrm{P}\left(\mathrm{P}_{\mathrm{BD}}\right)$, and non-reactive $\mathrm{P}$ extracted in $\mathrm{H}_{2} \mathrm{O}\left(\mathrm{nrP}_{\mathrm{H}_{2} \mathrm{O}}\right)$, in $\mathrm{BD}\left(\mathrm{nrP}_{\mathrm{BD}}\right)$ and in $\mathrm{NaOH}$ $\left(n r P_{\mathrm{NaOH}}\right)$ because these fractions constitute the $\mathrm{P}$ that can be released during anoxic periods and through the degradation of organic matter (Reitzel et al., 2005).

$\mathrm{Fe}$ oxides were obtained from the BD extracts $\left(\mathrm{Fe}_{\mathrm{BD}}\right)$ used for $\mathrm{P}$ speciation (Jensen \& Thamdrup, 1993). For the determination of TFe, the sediment was combusted following the same methodology described for $\mathrm{TP}_{\text {sed }}$. TFe and $\mathrm{Fe}_{\mathrm{BD}}$ were measured spectrophotometrically using the 
ferrozine method (Gibbs, 1979). For calculating the $\mathrm{Fe}: \mathrm{P}$ ratio, the $\mathrm{Fe}$ and $\mathrm{P}$ sedimentary forms must be specified. As $\mathrm{FeOOH}\left(\mathrm{Fe}_{\mathrm{BD}}\right)$ is the most important $\mathrm{Fe}$ sedimentary pool contributing to $\mathrm{P}$ adsorption capacity and mobile $\mathrm{P}$ represents sedimentary $\mathrm{P}$ fractions that are more easily subject to mobilisation, we have examined the FeOOH: P mobile ratio.

OM concentration was quantified as LOI $\left(520^{\circ} \mathrm{C}, 3 \mathrm{~h}\right) . \mathrm{C}$ and $\mathrm{N}$ concentrations were determined using a CNH Elemental Analyser.

\section{Quantification of macrophyte cover}

For the period from January 2008 to December 2009, we used 20 satellite images taken by the TM and ETM+ sensors on board the Landsat 5 and Landsat 7 satellites, obtained from the United States Geological Survey. We applied the Normalised Difference Vegetation Index (NDVI, Mather, 1987), which estimates the fraction of active photosynthetic radiation that is intercepted by vegetation (Alcaraz-Segura et al., 2008) and is based on the reflectance in the red (R) and near infrared (NIR) bands (bands 3 and 4, respectively, for Landsat images). Using ENVI 4.4 software, one mask was constructed for the total lake surface and a second mask for the vegetation cover. These masks were combined to obtain one that contained only aquatic vegetation. The mask area was quantified by the number of pixels (30 $\mathrm{m} \times 30 \mathrm{~m}$ each).

\section{Statistical Analysis}

Statistical analysis was performed using Statistica 6.0 Software (StatSoft Inc, 1997). Student t-tests were used to evaluate differences between paired or unpaired datasets. The significance level was established at $p<0.05$ unless otherwise stated.

When necessary, data were log-transformed to comply with normality assumptions. All chemi-
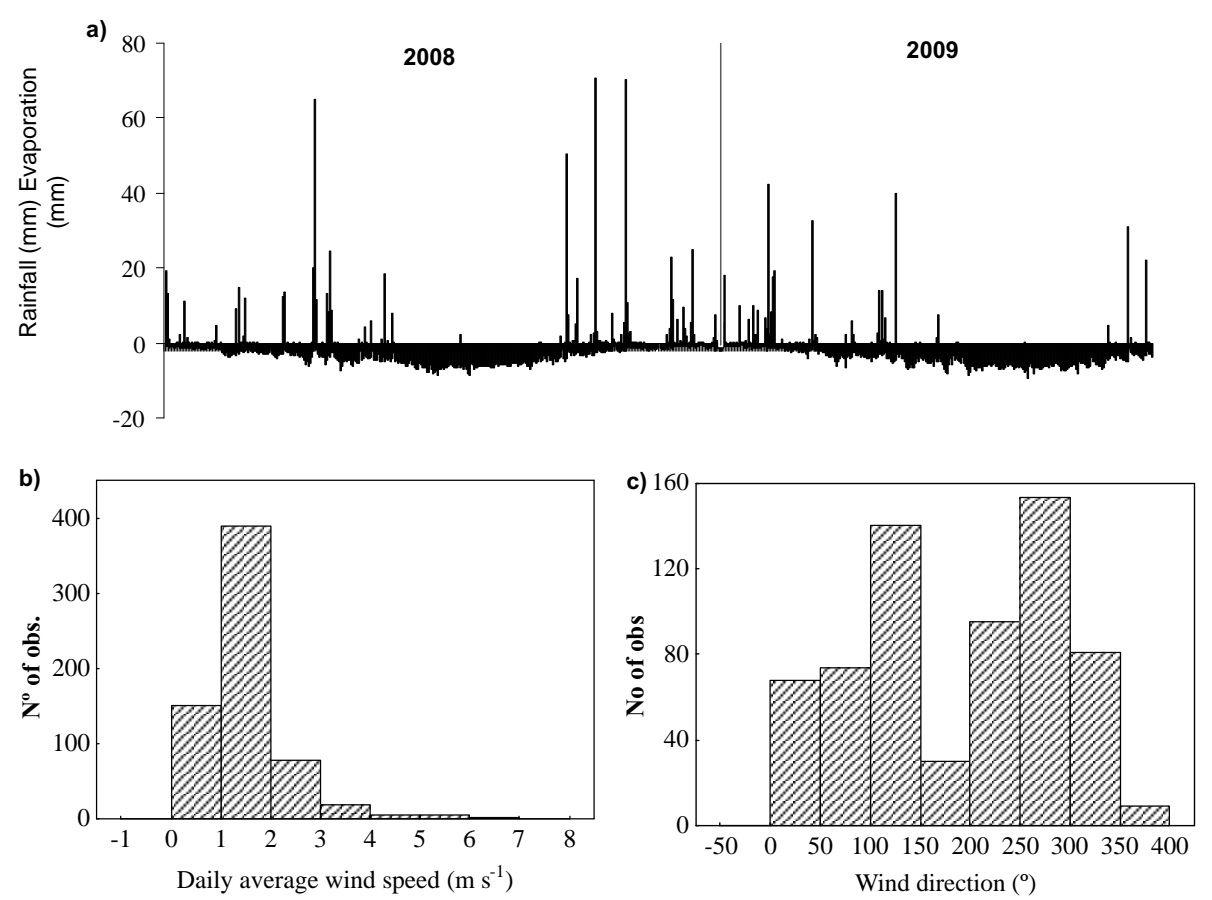

Figure 2. Temporal evolution of daily rainfall (positive) and daily evaporation (negative) (a) and histograms of daily average wind speed (b) and wind direction (c). All data are for the period 01/01/2008-11/10/2009. Data provided by www.juntadeandalucia.es/agriculturaypesca/ifapa/ria (Jerez de la Frontera, 36 38 $38^{\prime \prime} \mathrm{N}, 06^{\circ} 00^{\prime} 44^{\prime \prime}$ W). Evolución temporal de la precipitación diaria (positiva) y de la evaporación diaria (negativa) (a) e histogramas del promedio diario de la velocidad del viento (b) y de la dirección del viento (c). Todos los datos corresponden al periodo 01/01/2008-11/10/2009. Datos proporcionados por

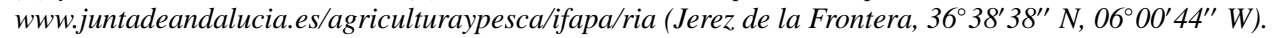


cal analyses were performed in duplicate (coefficient of variation, $\mathrm{CV}=8 \%$ ).

\section{RESULTS}

Medina Lake is subject to the typical temporal fluctuations in weather forcings that characterise the Mediterranean climate (Fig. 2a). Sporadic and strong peaks in rainfall occur during the spring and autumn. In fact, during just one day (31/10/2008), up to $10 \%$ of the year's accumulated rainfall was recorded. Evaporation rates were highest in the summer as a consequence of high air temperatures. The study site is relatively windy (Fig. $2 b$ for daily average wind speed). Most of the observations correspond to values ranging from 1 to $2 \mathrm{~m} \mathrm{~s}^{-1}$, although $3 \%$ of the

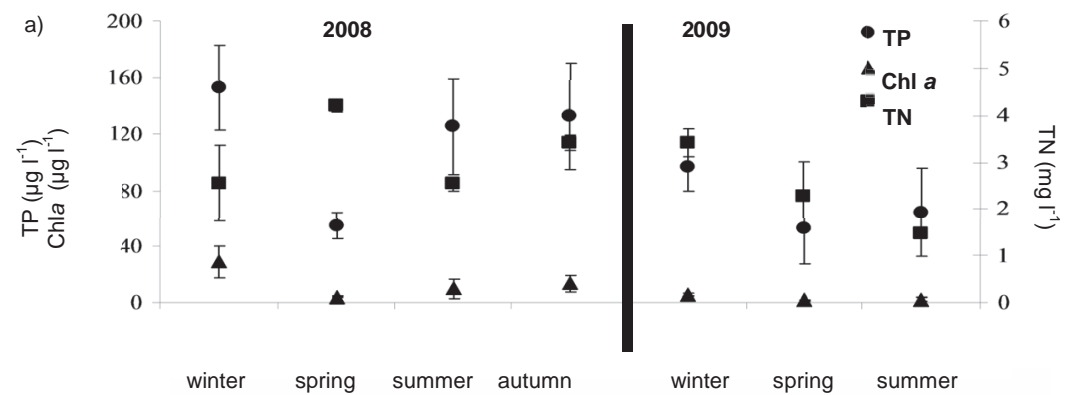

b)

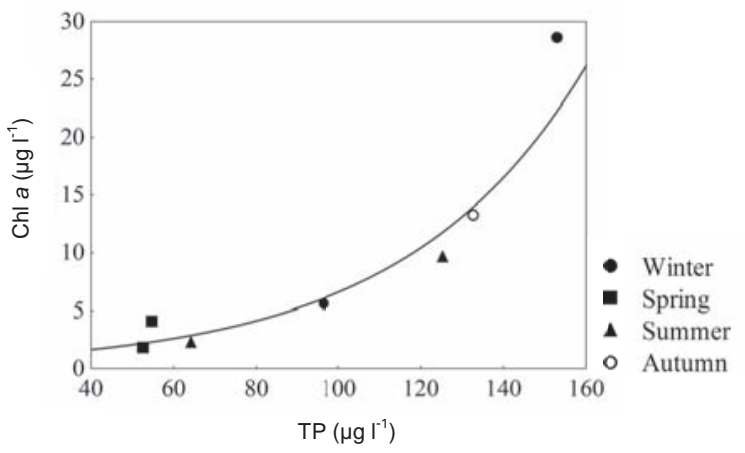

c)

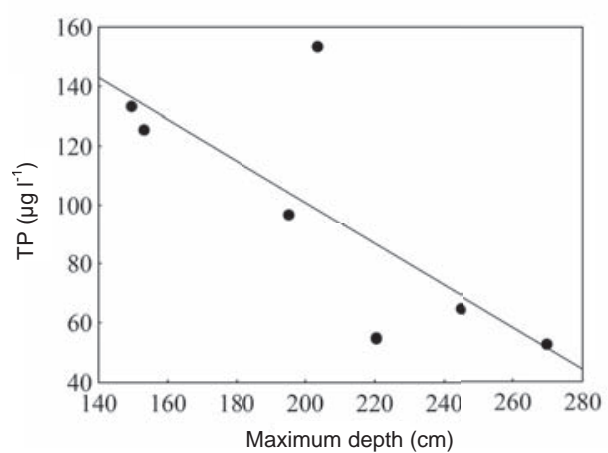

Figure 3. TP, TN and Chl $a$ concentrations (a) and scatterplots of TP vs. Chl $a$ (b) and maximum water depth vs. TP (c). The vertical bars in (a) represent the SD considering the surface and bottom waters at the 5 sampling stations. The data points in (b) refer to mean values from figure $3 \mathrm{a}(r=0.87 ; p<0.05)$. Concentración de TP, TN y Chl a (a) y regresión entre TP y Chl a $(b)$ y entre la profundidad máxima y la concentración de TP $(c)$. Las barras verticales en (a) representan la desviación estándar (SD) considerando muestras de agua de superficie y de fondo en las 5 estaciones de muestreo. Los datos representados con puntos en (b) se refieren a los valores promedios de la figura $3 a(\mathrm{r}=0.87 ; \mathrm{p}<0.05)$. 
observed values were greater than $4 \mathrm{~m} \mathrm{~s}^{-1}$. Wind direction was primarily south-east $\left(100-150^{\circ}\right)$ and west $\left(250-300^{\circ}\right)$ (Fig. 2c). Thus, wind frequently blows along the line of maximum fetch (W-E) (Fig. 1).

\section{Two-year and daily monitoring of the water column}

Marked inter- and intra-annual fluctuations in TN, TP and Chl $a$ concentration were observed (Fig. 3a). In general, TP and Chl $a$ concentrations showed similar temporal patterns over the study period, with the highest values recorded during the winter of 2008 and the lowest during the spring of 2009. The two variables were positively correlated ( $r=0.87 ; p<0.05)$ (Fig. 3b). Although not shown in the figure, the spatial homogeneity was highest during the spring of 2008, reflected by the lowest value of the coefficient of variation (CV) for the TP and Chl $a$ concentrations. In contrast, TN concentrations were highest during the spring of 2008 and lowest during the summer of 2009. TP concentrations in the water column were significantly and inversely related to maximum water depth $(r=-0.76 ; p<0.05$; Fig. 3c).
Contrasting meteorological forcings occurred during both intensive samplings (winter and spring 2008). The maximum wind speed was significantly lower $(p<0.001)$ in the winter $\left(3.5 \mathrm{~m} \mathrm{~s}^{-1}\right)$ than in the spring of $2008(5.4 \mathrm{~m}$ $\mathrm{s}^{-1}$ ) (Fig. 4). Similarly, significant differences in nutrient, Chl $a$ and TSS concentrations were found (Figs. 5 and 6). TP and TDP were significantly higher $(p<0.005)$ in the winter of 2008 , whereas an inverse tendency was observed for SRP, TN, TDN, $\mathrm{NO}_{3}^{-}$and $\mathrm{NH}_{4}^{+}$concentrations. SRP comprised less than $1 \%$ of the TDP in the winter of 2008, but this percentage increased to $22 \%$ in the spring of 2008 . A change in the dissolved inorganic nitrogen (DIN) fraction was also observed, with a predominance of $\mathrm{NO}_{3}^{-}$in the winter of 2008 (27\% of the TDN) and of $\mathrm{NH}_{4}^{+}$in the spring of 2008 (62\% of the TDN). Despite these differences, the DIN:SRP atomic ratio was much greater than 16 during both intensive surveys, indicating strong $\mathrm{P}$ limitation of primary production. Chl $a$ and POM concentrations were also significantly higher in the winter of 2008 than in the spring of 2008. In fact, the average Chl $a$ concentration was 8 times higher in the winter of 2008. In contrast, no differences in PIM concentrations were observed. A

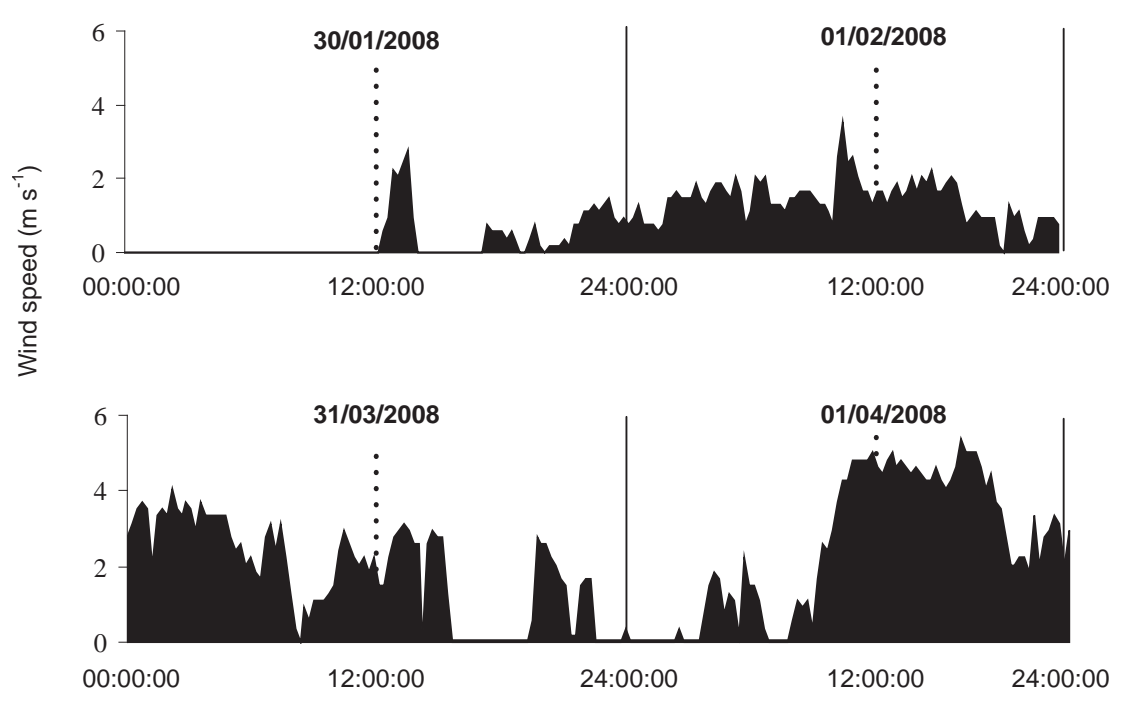

Figure 4. Temporal variation in wind speed during the intensive surveys. Data are shown for every 15 min. Variación temporal de la velocidad del viento durante los muestreos intensivos. Datos mostrados cada 15 minutos. 

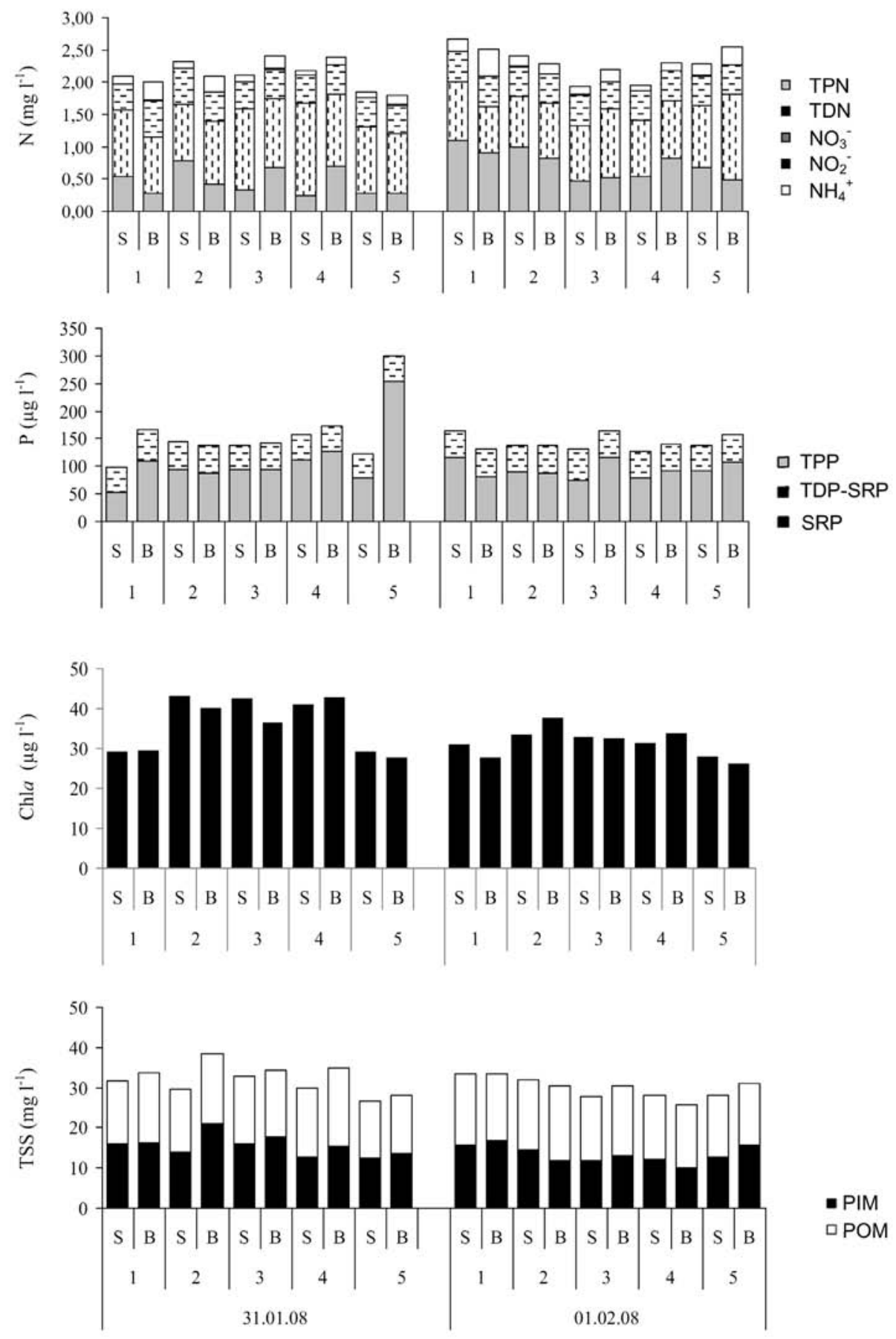

Figure 5. Results of the intensive survey carried out during 31/01/2008-01/02/2008. Only the results from samples collected at 17:00 $\mathrm{h}$ on each day are shown. $\mathrm{S}$ and $\mathrm{B}=$ surface $(10 \mathrm{~cm}$ below surface $)$ and bottom waters $(20 \mathrm{~cm}$ above sediments $)$, respectively; 1-5: sampling stations. TPN was estimated as the difference between TN and TDN. Resultados de los muestreos intensivos realizados durante 31/01/2008-01/02/2008. Sólo se muestran los datos de las muestras tomadas, cada día, a las 17:00 h. S y B = agua superficial (10 cm desde la superficie) y agua de fondo (20 cm por encima del sedimento); 1-5: estaciones de muestreo. TPN fue estimado como la diferencia entre TN y TDN. 

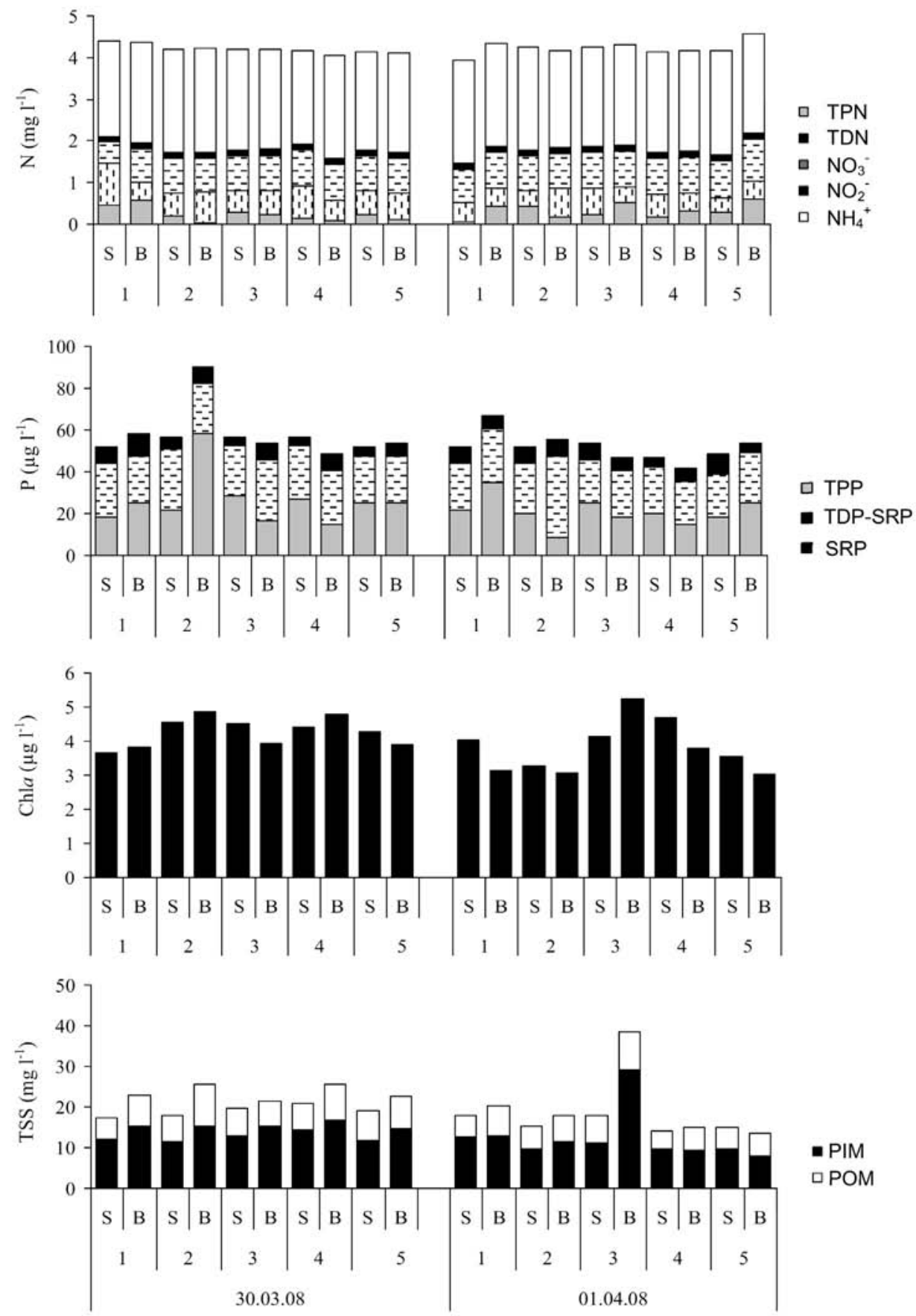

Figure 6. Results of the intensive survey carried out during 31/03/2008-01/04/2008. S and B = surface (10 cm below surface) and bottom waters (20 cm above sediments), respectively; 1-5: sampling stations. TPN was estimated as the difference between TN and TDN. Resultados de los muestreos intensivos realizados durante 31/03/2008-01/04/2008. S y B=agua superficial (10 cm desde la superficie) y agua de fondo (20 cm por encima del sedimento); 1-5: estaciones de muestreo. TPN fue estimado como la diferencia entre TN y TDN. 
Table 2. Daily settling rates, percentage of resuspension (\% Res) and chemical characterisation of both resuspended (RM) and settling matter (SM) during two intensive sampling periods (winter 2007-2008 and spring 2008). Tasa diaria de sedimentación, porcentaje de resuspensión (\% Res) y caracterización química del material resuspendido (RM) y de la materia sedimentada (SM) durante dos muestreos intensivos (invierno 2007-2008 y primavera 2008).

\begin{tabular}{|c|c|c|c|c|c|c|c|}
\hline & Station & $\begin{array}{l}\text { Depth } \\
(\mathrm{m})\end{array}$ & Sample & $\begin{array}{l}\mathrm{OM} \\
(\%)\end{array}$ & $\begin{array}{c}\mathrm{TFe} \\
\left(\mathrm{mg} \mathrm{g}^{-1} \mathrm{dw}\right)\end{array}$ & $\begin{array}{c}\text { Sed. flux } \\
\left(\mathrm{g} \mathrm{m}^{-2} \mathrm{~d}^{-1}\right)\end{array}$ & $\begin{array}{l}\text { Res } \\
(\%)\end{array}$ \\
\hline \multirow{5}{*}{$31 / 01-01 / 02 / 2008$} & 1 & 1.8 & SM & 28.5 & - & 31.0 & - \\
\hline & 2 & 1.9 & SM & 35.0 & - & 26.5 & - \\
\hline & 3 & 1.9 & SM & 33.8 & - & 30.6 & - \\
\hline & 4 & 1.8 & SM & 36.8 & - & 31.3 & - \\
\hline & 5 & 1.7 & SM & 32.7 & - & 40.0 & - \\
\hline \multirow{10}{*}{$31 / 03-01 / 04 / 2008$} & 1 & 1.6 & $\mathrm{RM}$ & 7.9 & 15.64 & 47.9 & 36.6 \\
\hline & & & SM & 23.3 & 5.73 & & \\
\hline & 2 & 1.6 & $\mathrm{RM}$ & 8.2 & 18.95 & 59.9 & 47.0 \\
\hline & & & SM & 21.1 & 8.91 & & \\
\hline & 3 & 1.7 & $\mathrm{RM}$ & 15.8 & 20.51 & 51.1 & 35.5 \\
\hline & & & SM & 21.6 & 7.29 & & \\
\hline & 4 & 1.6 & $\mathrm{RM}$ & 14.5 & 15.87 & 48.5 & 13.8 \\
\hline & & & SM & 25.7 & 2.19 & & \\
\hline & 5 & 1.5 & $\mathrm{RM}$ & 18.3 & 18.19 & 38.7 & 23.2 \\
\hline & & & SM & 23.4 & 4.23 & & \\
\hline
\end{tabular}

strong positive correlation $(r=0.95 ; p<0.001)$ between POM and Chl $a$ was found when merging all data from the two intensive samplings. Overall, no clear horizontal or vertical pattern in nutrient, Chl $a$ and TSS concentrations emerged from the intensive surveys.

\section{Resuspension and settling fluxes}

Daily settling rates were significantly higher $(p<0.005)$ in the spring of $2008(49.2 \pm 7.6 \mathrm{~g}$ DW $\left.\mathrm{m}^{-2} \mathrm{~d}^{-1}\right)$ than in the winter of 2008 $\left(31.9 \pm 4.9 \mathrm{~g} \mathrm{DW} \mathrm{m}^{-2} \mathrm{~d}^{-1}\right)$ (Table 2). Spatial variability in settling rates was similar during both intensive samplings, as reflected by a similar coefficient of variation (15\%). There was no clear spatial trend in sedimentation patterns in any of the surveys. The OM concentration in settling matter was significantly higher in winter $(33.4 \pm 3.1 \%)$ than in the spring of $2008(23.0 \pm 1.8 \%)$. Settling matter $(23.0 \pm 1.8 \%)$ was significantly more enriched in $\mathrm{OM}$ than resuspended matter $(13.0 \pm 4.7 \%)$, whereas the TFe concentration was significantly lower $(p<0.001)$ in settling matter $\left(5.7 \pm 2.6 \mathrm{mg} \mathrm{Fe}^{-1} \mathrm{DW}\right)$ than in resuspended matter $\left(17.8 \pm 2.0 \mathrm{mg} \mathrm{Fe}^{-1} \mathrm{DW}\right)$ (Table 2). Resuspension rates ranged from 13.8 $\%$ at Station 4 to $47.0 \%$ at Station 2 .

\section{Surface sediment characterisation}

The OM concentration was significantly higher $(p<0.005)$ in the winter $(6.0 \pm 1.1 \%)$ than the summer $(3.1 \pm 1.0 \%)$ (Fig. 7a). In fact, the OM concentration was more than twice as high in the winter at Stations 3, 4 and 5 than in the summer. Spatial heterogeneity was more pronounced in July $(\mathrm{CV}=32 \%)$, with higher OM concentrations in the eastern part of the lake (Station 1).

$\mathrm{Fe}_{\mathrm{BD}}$ was also significantly higher $(p<0.005)$ in the winter $\left(3.64 \pm 0.50 \mathrm{mg} \mathrm{Fe} \mathrm{g}{ }^{-1} \mathrm{DW}\right)$ than the summer $\left(1.25 \pm 0.72 \mathrm{mg} \mathrm{Fe}^{-1} \mathrm{DW}\right.$ ) (Fig. $7 b)$. The $\mathrm{Fe}_{\mathrm{BD}}$ concentration was extremely heterogeneously distributed in the summer $(\mathrm{CV}=58 \%)$, when peaks of $\mathrm{Fe}_{\mathrm{BD}}$ were again found in the eastern site of the lake (Station 1). In contrast, no significant differences were observed in $\mathrm{TFe}$ concentration between the winter $\left(30.40 \pm 7.01 \mathrm{mg} \mathrm{Fe} \mathrm{g}^{-1} \mathrm{DW}\right)$ and the summer $\left(29.23 \pm 12.72 \mathrm{mg} \mathrm{Fe}^{-1} \mathrm{DW}\right)$. A more homogeneous spatial distribution was observed during winter sampling $(\mathrm{CV}=23 \%)$ than during the summer $(\mathrm{CV}=43 \%)$, when the highest concentration was measured at Station 3.

In general, $\mathrm{Fe}_{\mathrm{BD}}$ represented a small fraction of TFe. However, remarkable differences between the two sampling periods emerged. A 
significantly higher contribution of $\mathrm{Fe}_{\mathrm{BD}}$ to the TFe pool was found in the winter $(13 \pm 4 \%)$ than in the summer $(5 \pm 4 \%)$. The $\mathrm{Fe}_{\mathrm{BD}}$ : $\mathrm{P}_{\mathrm{BD}}$ atomic ratio ranged from 11 to 19 in the winter and from 2 to 10 in the summer. Accordingly, significantly higher values were measured in the winter $(14 \pm 3)$ than in the summer $(4 \pm 3)$. Extreme spatial heterogeneity was observed in the summer $(\mathrm{CV}=86 \%)$, when the highest values were measured at Station 1.
No significant temporal differences were observed in TP concentration in any of the sedimentary $\mathrm{P}$ fractions (Fig. 7c). The $\mathrm{P}$ concentration in the sediment consisted primarily of $\mathrm{P}_{\mathrm{HCl}}$, which accounted, on average, for $48 \%$ and $53 \%$ of TP during the winter and summer, respectively. $P$ mobile was significantly higher in the winter $\left(394 \pm 53 \mu \mathrm{g} \mathrm{P} \mathrm{g}^{-1} \mathrm{DW}\right)$ than in the summer $\left(283 \pm 84 \mu \mathrm{g} \mathrm{P} \mathrm{g}^{-1} \mathrm{DW}\right)$, comprising from $25 \%$ (summer) to $37 \%$ (winter) of the TP.
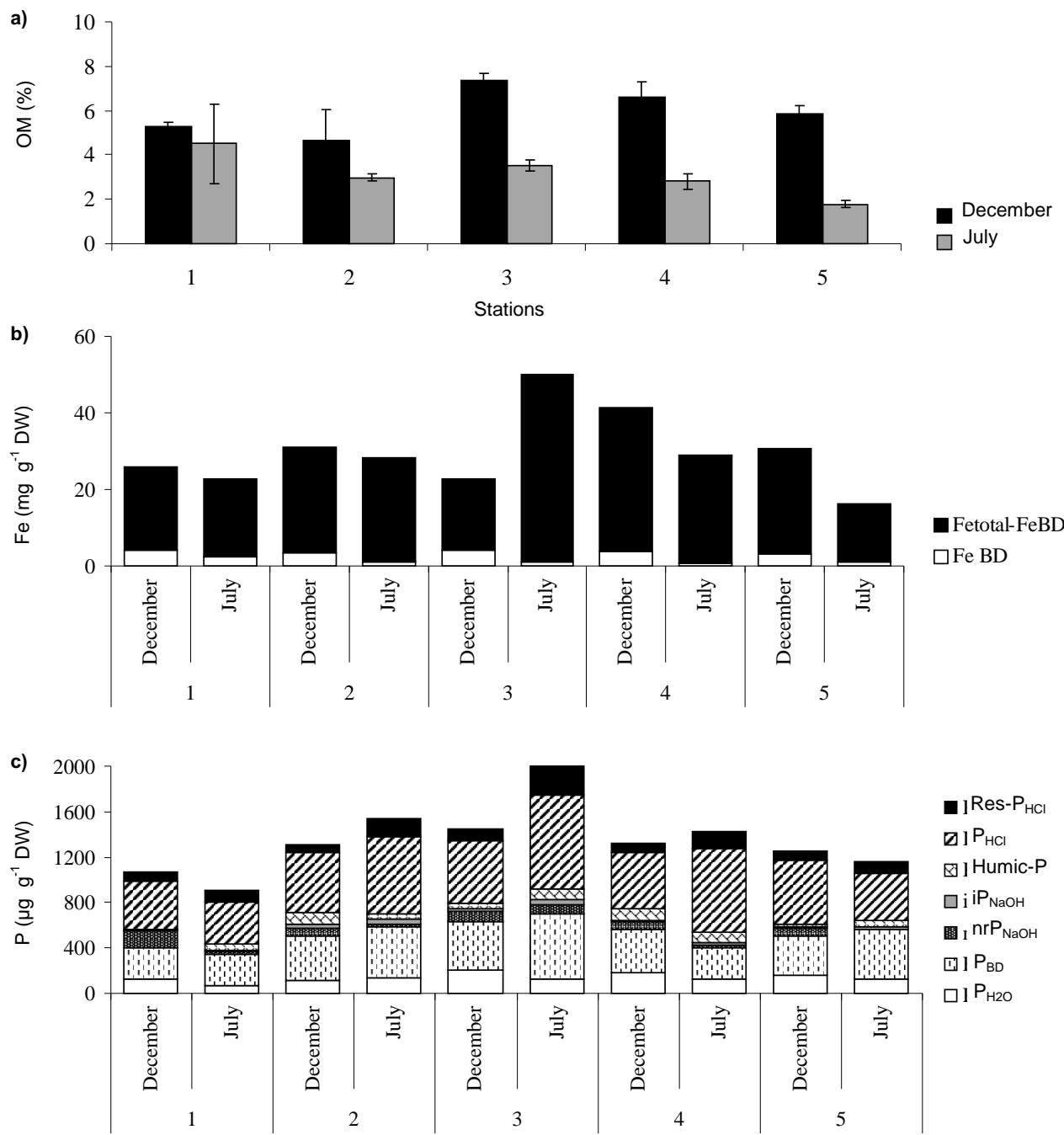

Figure 7. Variations in $\mathrm{OM}$ concentration (a) including vertical bars that represent the $\mathrm{SD}$ of duplicates, $\mathrm{TFe}$ and $\mathrm{Fe}$ oxides (Fe $\mathrm{BD}$ ) (b) and in sedimentary P fractions (c) of the surface sediment $(0-0.5 \mathrm{~cm}) . n=3$ per station. Variaciones en el contenido de materia orgánica (a) incluyendo en barras verticales la $S D$ de las réplicas, $T F e$ y óxidos de $F e\left(F e_{B D}\right)(b)$ y en fracciones de $P$ sedimentario (c) en el sedimento superficial $(0-0.5 \mathrm{~cm}) . \mathrm{n}=3$ en cada estación. 


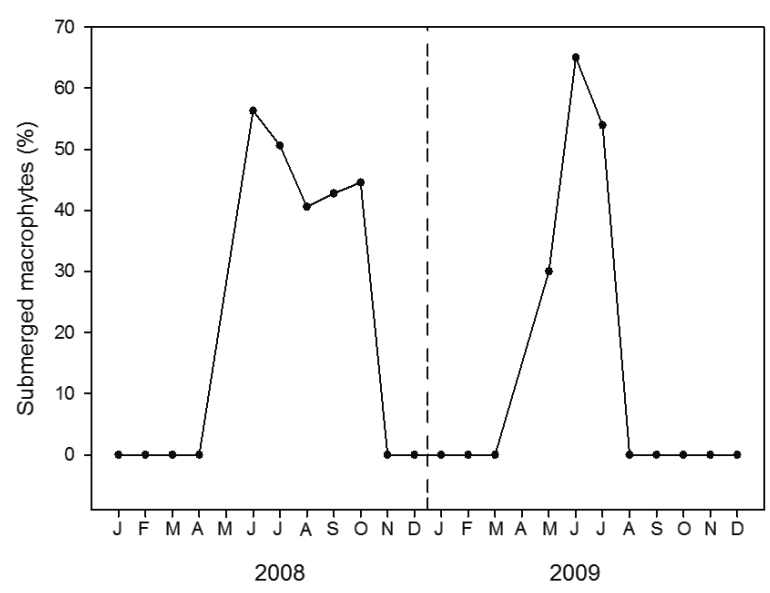

Figure 8. Development of macrophyte cover in Medina Lake according to an analysis of Landsat satellite images. No images were available for January or December 2008, but field visits showed that no macrophytes were present. Variación temporal de la cobertura por macrófitos acuáticos en la laguna de Medina mediante el análisis de imágenes de satélite. A pesar de la ausencia de imágenes en Enero y Diciembre de 2008, los muestreos rutinarios nos permitieron reconocer la ausencia de macrófitos.

\section{Changes in macrophyte cover}

The proportion of the lake surface covered with submerged macrophytes varied from zero in winter months to $30-65 \%$ in summer months (Fig. 8).

\section{DISCUSSION}

This study confirmed the high temporal (inter and intra-annual) variability of the nutrient and sediment dynamics characterising Mediterranean shallow lakes (i.e., de Vicente et al., 2006b). Due to this variability, the study of shallow lakes may require a greater reliance on lake-specific research results and less inter-lake generalisation than is possible for deeper systems. However, our knowledge of shallow lakes, especially Mediterranean shallow lakes, is still limited (Becares et al., 2004; Beklioglu et al., 2007). A major factor contributing to the marked temporal variability of these ecosystems is water level fluctuations. In fact, as recorded in other Mediterranean lakes (García-Jurado, 2012), in Medina Lake we found a significant and inverse relationship between TP concentrations in the water column and maximum water depth, reflecting the effects of both nutrient concentration and resuspension when the water level becomes low.

Short-term monitoring at the study site revealed that not only meteorological forcing but also biological structure are crucial for wholelake functioning. Therefore, although maximum wind speed was much higher in the spring, the existence of dense macrophyte beds reduced the impact of wind-induced Resuspension, as reflected by the lower TSS concentrations. In addition to affecting sediment and water interactions by limiting wind-induced resuspension and taking up interstitial $\mathrm{P}$ through their root systems, macrophytes also critically affect plankton dynamics (Scheffer et al., 1993). In plant-dominated shallow lakes, macrophytes can limit the growth of phytoplankton and periphyton by competing with algae for nutrients (Ozimek et al., 1993), shading their competitors (Kairesalo, 1984; Sand-Jensen \& Borum, 1991; Cattaneo et al., 1998) and by harbouring grazers (Timms \& Moss, 1984; Lauridsen et al., 1996). This explains why we found very low values of Chl $a$ concentrations in Medina Lake, especially during the summer. The higher water temperatures, the reduction in water depth (up to $35 \%$ and $22 \%$ reductions during the summers of 2008 and 2009, respectively) and the higher light availability compared to the rest of the year enable the persistence of aquatic plants during the spring and summer periods (Green et al., 2009), promoting a clear-water phase. As a result, based on the annual average Chl $a$ concentration and following the thresholds for shallow lakes proposed by Moss et al. (2003), we could classify Medina Lake as being of high water quality. In contrast, a strong discrepancy exists when evaluating trophic state considering annual average TP concentrations (from poor water quality during 2008 to moderate during 2009). These results highlight the need for further research for establishing more specific thresholds for Mediterranean shallow lakes, where the mild climate can allow macrophyte beds to persist for longer periods.

A major factor contributing to the marked instability characterising shallow lake functioning 
is the close link between bottom sediments and overlying waters. The potential importance of sediment-water interactions in the $\mathrm{P}$ cycling of Medina Lake is illustrated by a simple comparison of available $\mathrm{P}$ forms in lake water and lake sediments. Considering the whole lake, the upper $1 \mathrm{~cm}$ sediment layer holds $6.53 \mathrm{Tm}$ of mobile $\mathrm{P}$, which is 18 times the mass of TP in the lake water. In fact, this calculation is an underestimate, as some authors consider that the mobile $\mathrm{P}$ contained in the upper $10 \mathrm{~cm}$ can potentially be released into lake water (Reitzel et al., 2005). The bioturbation of sediments by water birds in Medina Lake may promote such $\mathrm{P}$ release from deeper sediments (Rodríguez-Pérez \& Green, 2006). Additionally, and although other specific approaches are recommended in the literature, there exists a strong P limitation of planktonic primary production in the study site, as reflected by a DIN:SRP atomic ratio well over 16 (Morris \& Lewis, 1988). Based on these results, P exchange across the sediment-water interface represents a crucial process for explaining $\mathrm{P}$ availability in the water column.

Sediments can act either as a sink or as a source of $\mathrm{P}$ according to the net consequences of a complex set of processes. Resuspension, precipitation with $\mathrm{CaCO}_{3}$ and adsorption onto FeOOH are among the most relevant physical and chemical processes affecting $P$ exchange across the sediment-water interface. Sediment resuspension can significantly modify the biogeochemistry of shallow aquatic ecosystems (e.g., Kristensen et al., 1992; Evans, 1994; Bloesch, 1995; Weyhenmeyer et al., 1995; Scheffer, 1998; Golterman, 2004). As a consequence of resuspension, the concentration of particulate matter in the water column increases, leading to reduced light penetration. To clarify the role of wind-induced resuspension on the turbidity of Medina Lake, we correlated the maximum wind speed recorded during a 48 hour period before the sampling $\left(w s_{48}\right)$ and TSS and total particulate phosphorus (TPP) concentrations. We found a positive and statistically significant relationship between $w s_{48}$ and TSS $(r=0.77 ; p<0.05 ; n=8)$, showing the role of wind forcing on the light climate in the study site. However, the positive relationship observed between TSS and TPP was not statistically significant $(r=0.66 ; p>0.05$; $n=6$ ), reflecting the variety of other processes involved in P cycling. The almost flat bottom of the study site is responsible for horizontal homogeneity in resuspension rates. However, the existence of prevailing winds blowing along the main axis (E-W) caused a slight increase in resuspension rates at stations located along this axis (1, 2 and 3), whereas lower values are exhibited at stations closer to the shoreline (4 and 5).

In addition, $\mathrm{P}$ adsorption by resuspended matter is a crucial process for retaining this nutrient in lake sediments. The effectiveness of P adsorption critically depends on several factors. Among them, the degree of saturation is particularly important, and this, in turn, can be related to the Fe:P ratio and reflects the number of free adsorption sites (Jensen \& Andersen, 1992; Jensen et al., 1992). The 3.5-fold higher FeOOH: $\mathrm{P}$ mobile ratio (by weight) in the winter (25) compared to the summer (7) suggests a higher capacity of Medina sediments to adsorb $P$ in winter when there are more free adsorption sites. Furthermore, our results show that, as according to Jensen et al. (1992), internal P-loading may be controlled by $\mathrm{P}$ adsorption onto oxidised surface sediments in the winter (Fe:P $>15)$, whereas in the summer, the low ratio $(\mathrm{Fe}: \mathrm{P}<15)$ reflects the lack of sufficient $\mathrm{FeOOH}$ to control P adsorption. The seasonal reduction in the $\mathrm{FeOOH}$ : $\mathrm{P}$ mobile ratio was a consequence of a notable reduction in $\mathrm{FeOOH}$ concentrations in the summer. This observation has frequently been made elsewhere during anoxic conditions in the summer months (Boström et al., 1982). As a result, $\mathrm{P}$ mobile that is partly bound to $\mathrm{FeOOH}$ was notably reduced (30\% reduction) during the summer. The close coupling between the sediment and water in Medina Lake is reflected by the 3 -fold increase in SRP concentrations in the water column in the summer compared to the winter. It is also noteworthy that the most important organic P pool $\left(\mathrm{nrP}_{\mathrm{NaOH}}\right)$ drastically decreased from winter to summer as a consequence of the intense OM mineralisation promoted by higher water temperatures.

Because the most important sedimentary inorganic $\mathrm{P}$ pool in Medina Lake is represented by $\mathrm{P}$ bound to $\mathrm{Ca}\left(\mathrm{P}_{\mathrm{HCl}}\right)$, it is important to study 
the precipitation process in detail. As suggested by Golterman (2004), the "apatite" compound is most likely a mixture of $\mathrm{CaCO}_{3}$ with apatite $\left(\mathrm{Ca}_{5}\left(\mathrm{PO}_{4}\right)_{3} \cdot \mathrm{OH}\right)$. The small $\mathrm{Ca}_{5}\left(\mathrm{PO}_{4}\right)_{3} \cdot \mathrm{OH}$ crystals may be adsorbed onto the much larger $\mathrm{CaCO}_{3}$ particles, both being traditionally abbreviated as $\mathrm{P} \approx \mathrm{CaCO}_{3}$. The maximum SRP concentration in the absence of $\mathrm{CaCO}_{3}$ precipitation can be calculated as a function of $\mathrm{Ca}^{2+}$ concentration and $\mathrm{pH}$ (Golterman, 2004). In Medina Lake, based on the average lake water $\mathrm{pH}$ (7.98), temperature $\left(21^{\circ} \mathrm{C}\right)$ and $\mathrm{Ca}^{2+}$ concentration (400 $\mathrm{mg}^{-1}$ ), the maximum SRP concentration would be lower than $5 \mu \mathrm{g}^{-1}$, a value well below the average SRP concentration measured in the lake during the study period $\left(11 \mu \mathrm{g}^{-1}\right)$, indicating the relevance of $\mathrm{CaCO}_{3}$ precipitation for removing $\mathrm{P}$ from lake water. Thus, the existence of SRP concentrations in lake water that are much higher than the threshold for $\mathrm{CaCO}_{3}$ and $\mathrm{P}$ co-precipitation is responsible for the high contribution of $\mathrm{P}$ bound to $\mathrm{CaCO}_{3}\left(\mathrm{P}_{\mathrm{HCl}}\right)$ to the Tot-P in the study site.

Sedimentation is a fundamental process connecting plankton with benthic communities (Bloesch \& Uehlinger, 1986). Although seasonal fluctuations and vertical variations in settling rate are recognised as important and have been widely studied (i.e., Hupfer et al., 1995; Penn \& Auer, 1997; de Vicente et al., 2005), horizontal differences have rarely been taken into account (Bloesch, 1982; Weyhenmeyer et al., 1997). In addition, although the exposure time for collecting settled matter has been identified as a key issue, most of the existing studies consider exposure times longer than two weeks (Pejrup et al., 1996; Weyhenmeyer et al., 1997). Owing to these limitations in previous studies, in this paper, horizontal variability in sedimentation rates was estimated considering an exposure time of 24 hours, thus assuring low losses by OM mineralisation. The daily settling rates measured in this study are among the highest values reported in the literature for natural inland waters (Tartari \& Biasci, 1997). Apart from confirming the positive relationship between trophic state and settling flux observed in natural water bodies (Tartari \& Biasci, 1997; de Vicente et al., 2005), these high values for settling rates corroborate the contribution of resuspended matter to gross sedimentation fluxes.

Overall, the large proportion of $\mathrm{P}$ mobile to the overall sedimentary $\mathrm{P}$ pool and its strong seasonal variability (a reduction of $32 \%$ from winter to summer) suggest that the P-limited Medina Lake is especially dependent on physical (wind-induced resuspension) and chemical $\left(\mathrm{CaCO}_{3}\right.$ precipitation and $\mathrm{P}$ adsorption on $\mathrm{FeOOH}$ ) processes affecting $\mathrm{P}$ exchange across the sediment-water interface.

\section{ACKNOWLEDGMENTS}

This research was funded by the Spanish Ministry of Science and Technology (DISPAR, CGL2005-00076) and by a contract with Ingeniería de Protección Ambiental, S.L. to investigate the success of restoration work (to AJG).

\section{REFERENCES}

ALVAREZ-COBELAS, M., C. ROJO \& D. G. ANGELER. 2005. Mediterranean limnology: current status, gaps and the future. J. Limnol., 64: 13-29.

APHA. 1995. Standard methods for examination of water and wastewater, nineteenth edition. APHAAWWA-WPCF, Washington D.C., USA.

AMAT, J. A. 1984. Las poblaciones de aves acuáticas en las lagunas andaluzas: composición y diversidad durante un ciclo anual. Ardeola, 31: 61-79.

BÉCARES, E., A. CONTY, C. RODRÍGUEZ-VILLAFAÑE \& S. BLANCO. 2004. Funcionamiento de los lagos someros mediterráneos. Ecosistemas, 2: (URL: http://www.aeet.org/ecosistemas/ 042/revision3.htm).

BEKLIOGLU, M., S. ROMO, I. KAGALOU, X. QUINTANA \& E. BÉCARES. 2007. State of the art in the functioning of shallow mediterranean lakes: workshop conclusions. Hydrobiol., 584: 317-326.

BENAVENTE, J., F. MORAL \& M. RODRÍGUEZRODRÍGUEZ. 2005. Definition of the hydrogeological setting of Andalusian wetlands. Playa-lakes of the province of Cadiz. Seville: Guadalquivir River Basin Authority. 182 pp.

BLOESCH, J. 1982. Inshore-offshore sedimentation differences resulting from resuspension in the 
eastern basin of Lake Erie. Can. J. Fish. Aquat. Sci., 39: 748-759.

BLOESCH, J. 1994. A review of methods used to measure sediment resuspension. Hydrobiol., 284: 13-18.

BLOESCH, J. 1995. Mechanisms, measurement and importance of sediment resuspension in lakes. Mar. Fresh. Res., 46: 295-304.

BLOESCH, J. \& U. UEHLINGER. 1986. Horizontal sedimentation differences in a eutrophic Swiss lake. Limnol. Oceanogr., 31: 1094-1109.

BOSTRÖM, B., M. JANSSON \& C. FORSBERG. 1982. Phosphorus release from lake sediments. Arch. Hydrobiol. Beih. Ergeb. Limnol., 18: 5-59.

BOSTRÖM, B., J. M. ANDERSEN, S. FLEISCHER \& M. JANSSON. 1988. Exchange of phosphorus across the sediment-water interface. Hydrobiol., 170: 229-244.

CATTANEO, A., G. GALANTI \& S. ROMO. 1998. Epiphytic algae and macroinvertebrates on submerged and floating-leaved macrophytes in an Italian lake. Freshwat. Biol., 39: 725-740.

DE VICENTE, I., V. AMORES, C. ESCOT, A. BASANTA \& L. CRUZ-PIZARRO. 2005. Temporal and spatial trends in the sedimentation process in a canyon-type reservoir (El Gergal, Seville, Spain). Arch. Hydrobiol., 163: 241-257.

DE VICENTE, I., V. AMORES \& L. CRUZ-PIZARRO. 2006a. Instability of shallow lakes: a matter of the complexity of factors involved in sediment and water interactions? Limnetica, 25: 253-270.

DE VICENTE, I., E. MORENO-OSTOS, F. J. RUEDA, V. AMORES \& L. CRUZ-PIZARRO. 2006 b. Low predictability in the dynamics of shallow lakes: implications for their management and restoration. Wetlands, 26: 928-938.

DE VICENTE, I., F. Ø. ANDERSEN, H. C. B. HANSEN, L. CRUZ-PIZARRO \& H. S. JENSEN. 2010a. Water level fluctuations may decrease phosphate adsorption capacity of the sediment in oligotrophic high mountain lakes. Hydrobiol., 651: 253-264.

DE VICENTE, I., L. CRUZ-PIZARRO \& F. J. RUEDA. 2010b. Sediment resuspension in two adjacent shallow coastal lakes: controlling factors and consequences on phosphate dynamics. Aquat. Sci., 72: 21-31.

DITTRICH, M. \& R. KOSCHEL. 2002. Interaction between calcite precipitation (natural and artifi- cial) and phosphorus cycle in the hardwater lake. Hydrobiol., 469: 49-57.

DOREMUS, C. \& L. S. CLESCERI. 1982. Microbial metabolism in surface sediments and its role in the inmobilization of phosphorus in oligotrophic lake sediments. Hydrobiol., 91: 261-268.

DOWNING, J. A. 2010. Emerging global role of small lakes and ponds: little things means a lot. Limnetica, 29: 9-24.

EVANS, R. D. 1994. Empirical evidence of the importance of sediment resuspension in lakes. Hydrobiol., 284: 5-12.

GARCÍA-JURADO, F., I. DE VICENTE, A. GALOTTI, A. REUL, F. JIMÉNEZ-GÓMEZ \& F. GUERRERO. 2012. Effect of drought conditions on plankton community and on nutrient availability in an oligotrophic high mountain lake. Artic, Antartic and Alpine Res. (in press).

GÄCHTER, R. \& B. WEHRLI. 1998. Ten years of artificial mixing and oxygenation: no effect on the internal phosphorus loading of two eutrophic lakes. Environ. Sci. Technol., 32: 3659-3665.

GÄCHTER, R. \& B. MÜLLER. 2003. Why the phosphorus retention of lakes does not necessarily depend on the oxygen supply to their sediment surface. Limnol. Oceanogr., 48: 929-933.

GIBBS, M. M. 1979. A simple method for the rapid determination of iron in natural waters. Wat. Res., 13: 295-297.

GOLTERMAN, H. L. 2001. Fractionation and bioavailability of phosphates in lacustrine sediments: a review. Limnetica, 20: 15-29.

GOLTERMAN, H. L. 2004. The chemistry of phosphate and nitrogen compounds in sediments. Kluwer Academic Publishers, Dordrecht/ Boston/ London. 246 pp.

HUPFER, M., R. GÄCHTER \& R. GIOVANOLI. 1995. Transformation of phosphorus species in settling seston and during early sediment diagenesis. Aquat. Sci., 57: 305-324.

JENSEN, H. S. \& F. Ø. ANDERSEN. 1992. Importance of temperature, nitrate and $\mathrm{pH}$ for phosphorus release from aerobic sediments of four shallow eutrophic lakes. Limnol. Oceanogr., 37: 577-589.

JENSEN, H. S., P. KRISTENSEN, E. JEPPENSEN \& A. SKYTTHE. 1992. Iron:phosphorus ratio in surface sediment as an indicator of phosphate release from aerobic sediments in shallow lakes. Hydrobiol., 235/236: 731-743.

JENSEN, H. S. \& B. THAMDRUP. 1993. Iron-bound phosphorus in marine sediments as measured by 
bicarbonate-dithionite extraction. Hydrobiol., 253: 47-59.

JEFFREY, S. W. \& G. F. HUMPHREY. 1975. New spectrophotometric equations for determining chlorophylls a, b, c1 and c2 in higher plants, algae and natural phytoplankton. Biochem. Physiol., 167: 191-194.

KAIRESALO, T. 1984. The seasonal succession of epiphytic communities within an Equisetum fluviatile stand in lake Pääjarvi, Southern Finland. Int. Rev. Gesam Hydrobiol., 69: 475-505.

KLEEBERG, A. 2002. Phosphorus sedimentation in seasonal anoxic Lake Scharmützel, NE Germany. Hydrobiol., 472: 53-65.

KOSCHEL, R., B. JURGEN, G. PROFT \& F. RECKNAGEL. 1983. Calcite precipitation as a natural control mechanism of eutrophication. Arch. Hydrobiol., 98: 380-408.

KRISTENSEN, P., M. SØNDERGAARD \& E. JEPPESEN. 1992. Resuspension in a shallow eutrophic lake. Hydrobiol., 228, 101-109.

LAURIDSEN, T. L., L. J. PEDERSEN, E. JEPPESEN \& M. SONDERGAARD. 1996. The importance of macrophyte bed size for cladoceran composition and horizontal migration in a shallow lake. $J$. Plank. Res., 18: 2293-2294.

MARTÍNEZ-HARO, M., A. J. GREEN, P. ACEVEDO \& R. MATEO. 2011. Use of grit supplements by waterbirds: an experimental assessment of strategies to reduce lead poisoning. Eur. J. Wildl. Res., 57: 475-484.

MATEO, R., A. J. GREEN, L. LEFRANC, R. BAOS \& J. FIGUEROLA. 2007. Lead poisoning in wild birds from southern Spain: a comparative study of wetland areas and species affected, and trends over time. Ecotoxicol. Environ. Saf., 66: 119-126.

MEERHOFF, M. \& E. JEPPESEN. 2009. Shallow lakes and ponds. Encyclopedia of Inland Waters, Vol. 2: 645-655.

MORRIS, D. P. \& M. W. LEWIS. 1988. Phytoplankton nutrient limitation in Colorado mountain lakes. Freshwat. Biol., 20: 315-327.

MORTIMER, C. H. 1941. The exchange of dissolved substances between mud and water in lakes. $J$. Ecol., 30: 280-329.

MOSS, B., D. STEPHEN, C. ÁLVAREZ, E. BÉCARES, W. VAN DE BUND, S. E. COLLINGS, E. VAN DONK, E. DE EYTO, T. FELDMANN, C. FERNÁNDEZ-ALÁEZ, M. FERNÁNDEZALÁEZ, R. J. M. FRANKEN, F. GARCÍACRIADO, E. M. GROSS, M. GYLLSTRÖM,
L. A. HANSSON, K. IRVINE, A. JÄRVALT, J. P. JENSEN, E. JEPPESEN, T. KAIRESALO, R. KORNIJÓW, T. KRAUSE, H. KÜNNAP, A. LAAS, E. LILL, B. LORENS, H. LUUP, M. R. MIRACLE, P. NÕGES, T. NÕGES, M. NYKÄNEN, I. OTT, W. PECZULA, E. T. H. M. PEETERS, G. PHILLIPS, S. ROMO, V. RUSSELL，J. SALUJÕE，M. SCHEFFER，K. SIEWERTSEN, H. SMAL, C. TESCH, H. TIMM, L. TUVIKENE, I. TONNO, T. VIRRO, E. VICENTE \& D. WILSON. 2003. The determination of ecological status in shallow lakes-a tested system (ECOFRAME) for implementation of the European Water Framework Directive. Aquatic Conserv. Mar. Freshw. Ecosyst., 13: 507-549.

MURPHY, J. \& J. P. RILEY. 1962. A modified single solution method for the determination of phosphate in natural waters. Anal. Chim . Acta, 27: 3136.

NÕGES, P., L. TUVIKENE, T. NÕGES \& A. KISAND. 1999. Primary production, sedimentation and resuspension in large shallow Lake Võrtsjärv. Aquat. Sci., 61: 168-182.

OTZUKI, A. \& R. G. WETZEL. 1972. Coprecipitation of phosphate with carbonates in a marl lake. Limnol. Oceanogr., 17: 763-767.

OZIMEK, T., E. VAN DONK \& R. D. GULATI. 1993. Growth and nutrient uptake by two species of Elodea in experimental conditions and their role in nutrient accumulation. Hydrobiol., 251: 13-18.

PALUDAN, C. \& H. S. JENSEN. 1995. Sequential extraction of phosphorus in freshwater wetlands and lake sediment: significance of humic acids. Wetlands, 15: 365-373.

PENN, M. R. \& M. T. AUER. 1997. Seasonal variability in phosphorus speciation and deposition in a calcareous, eutrophic lake. Mar. Geol., 139: 4759.

PEJRUP, M., J. VALEUR \& A. JENSEN. 1996. Vertical fluxes of particulate matter in Aarhus Bight, Denmark. Cont. Shelf Res., 16: 1047-1064.

REED, J. M., A. C. STEVENSON \& S. JUGGINS. 2001. A multi-proxy record of Holocene climatic change in southwestern Spain: the Laguna de Medina, Cadiz. Holocene, 11: 707-719.

REITZEL, K., J. HANSEN, F. Ø. ANDERSEN \& H. S JENSEN. 2005. Lake restoration by dosing aluminum relative to mobile phosphorus in the sediment. Environ. Sci. Technol., 39: 4134-4140. 
RODIER, J. 1989. Análisis de las aguas. Ed. Omega, Barcelona, Spain. 1059 pp.

RODRIGO, M. A., E. VICENTE \& M. R. MIRACLE. 1993. Short-term calcite precipitation in the karstic meromictic lake La Cruz (Cuenca, Spain). Verh. Int. Verein. Limnol., 25: 711-719.

RODRÍGUEZ-PÉREZ, H. \& A. J. GREEN, A. J. 2006. Waterbird impacts on widgeongrass Ruppia maritima in a Mediterranean wetland: comparing bird groups and seasonal effects. Oikos, 112: 525-534.

RODRÍGUEZ-RODRÍGUEZ, M. 2007. Hydrogeology of ponds, pools and playa-lakes of Southern Spain. Wetlands, 27: 819-830.

RODRÍGUEZ-RODRÍGUEZ, M., A. J. GREEN, R. LÓPEZ \& S. MARTOS-ROSILLO. 2011. Changes in water level, land use, and hydrological budget in a semi-permanent playa lake, southwest Spain. Environmental Monitoring and Assessment, DOI 10.1007/s10661-011-2002-1.

RYDING, S. O. 1985. Chemical and microbiological processes as regulators of the exchange of substances between sediments and water in shallow eutrophic lakes. Int. Rev. Ges. Hydrobiol., 70: 657702.

SAND-JENSEN, K. \& J. BORUM. 1991. Interactions among phytoplankton, periphyton and macrophytes in temperate freshwaters and estuaries. Aquat. Bot., 41: 137-175.

SCHEFFER, M. 1998. Ecology of shallow lakes. Chapman and Hall, London. 345 pp.

SCHEFFER, M., S. H. HOSPER, M. L. MEIJER, B.
MOSS \& E. JEPPESEN. 1993. Alternative equilibria in shallow lakes. Trends in Ecology and Evolution, 8: 275-279.

STATSOFT Inc. 1997. Statistica for Windows (computer program manual). Tulsa, Oklahoma, USA.

SMITH, L. M. 2003. Playas of the Great Plains. University of Texas Press, Texas, TX, USA.

TARTARI, G. \& G. BIASCI. 1997. Trophic status and lake sedimentation fluxes. Wat. Air Soil Pollut., 99: 523-531.

TIMMS, R. M. \& B. MOSS. 1984. Prevention of growth of potentially dense phytoplankton populations by zooplankton grazing, in the presence of zooplanktivorous fish, in a shallow wetland ecosystem. Limnol. Oceanogr., 29: 472-486.

WEYHENMEYER, G. A., M. MEILI \& D. C. PIERSON. 1995. A simple method to quantify sources of settling particles in lakes: Resuspension versus new sedimentation of material from planktonic production. Mar. Fresh. Res., 46: 223-231.

WEYHENMEYER, G. A., L. HAKÅNSON \& M. MEILI. 1997. A validated model for daily variations in the flux, origin and distribution of settling particles within lakes. Limnol. Oceanogr., 42: 1517-1529.

WEYHENMEYER, G. A. \& J. BLOESCH. 2001. The pattern of particle flux variability in Swedish and Swiss lakes. Sci. Tot. Environ., 266: 69-78.

YECHIELI, Y. \& W. W. WOOD. 2002. Hydrogeologic processes in saline systems: playas, sabkhas, and saline lakes. Earth-Science Reviews, 58: 34365. 